\title{
Türkiye'de Hanehalklarına Yapılan Sosyal Yardımların Belirleyicileri $^{1}$
}

\author{
Behice CANATAN \\ Tarsus Üniversitesi, Lisansüstü Enstitüsü, behicecanatan@tarsus.edu.tr, ORCID: \\ 0000-0001-9588-386X,
}

\author{
Egemen İPEK \\ Tarsus Üniversitesi, Uygulamalı Bilimler Fakültesi \\ egemenipek@tarsus.edu.tr,ORCID:0000-0002-1365-0526
}

\begin{abstract}
$\ddot{\mathbf{O z}}$
Sosyal yardımlar, ayni ve nakdi yardımlar aracılığıyla bireyler veya haneler arasındaki eşitsizlikleri önlemede kullanılan önemli sosyal politika araçlarından biridir. Sosyal yardımların kimlere ve hangi kriterlere göre verileceği ve sosyal yardım alıcılarının sosyoekonomik profillerinin incelenmesi, uygulanan sosyal yardımların verimliliğini ölçmek açısından önemlidir. Bu bağlamda çalışmanın amacı Türkiye İstatistik Kurumu'nun yapmış olduğu Hanehalkı Bütçe Anketi mikro veri setinden yararlanarak 2003-2015 y1lları arasında hanehalklarına yapılan sosyal yardımların, sosyoekonomik belirleyicilerini analiz etmektir. Analizde klasik regresyona yöntemine göre uç değerleri daha fazla dikkate alan kantil regresyon yöntemi kullanılmıştır. İncelenen yıllarda elde edilen önemli bulgular arasında kadınların, herhangi bir işte çalışmayan bireylerin ve bekârların daha fazla sosyal yardım aldı̆̆ı tahmin edilmiştir.
\end{abstract}

Anahtar Kelimeler: Sosyal Yardımlar, Hanehalkı, Kantil Regresyon, Türkiye Jel Sinıflandırma Kodları: C21, D6, H31

\section{Determinants of Social Benefit to Households in Turkey ${ }^{2}$}

\begin{abstract}
Social benefit is one of the crucial social policy tools used to eliminate the inequalities between individuals or households through in-kind and cash benefits. To determine the eligibility criteria for social benefits and examine the socio-economic determinants of social benefits are important in evaluating the efficiency of social benefits. In this context, this study aims to determine the socioeconomic determinants of social benefits to households using Household Budget Survey micro data sets for the period 2003-2015 provided by Turkey Statistical Institute. In the analysis the quantile regression method, which more considers the extreme values, is used. Among the most important findings of the study that women, unemployed, and single individuals receive more social benefits for all research periods and all quantiles.
\end{abstract}

Keywords: Social Benefit, Household, Quantile Regression, Turkey Jel Classification Codes: C21, D6, H31

\footnotetext{
${ }^{1} \mathrm{Bu}$ çalışma Behice CANATAN'ın Gümüşhane Üniversitesi Sosyal Bilimler Enstitüsü, İktisat Anabilim Dalı Tezli Yüksek Lisans programında Doç. Dr. Egemen IPEK danışmanlığında hazırlanan aynı başlıklı yüksek lisans tezinden üretilmiştir.

${ }^{2}$ Extended abstract is presented at the end of the article.

Geliş Tarihi (Received): 27.10.2020 - Kabul Edilme Tarihi (Accepted): 08.05.2021
}

Atıfta bulunmak için / Cite this paper:

Canatan, B. ve İpek, E. (2021). Türkiye'de hanehalklarına yapılan sosyal yardımların belirleyicileri. Çankırı Karatekin Üniversitesi IIIBF Dergisi, 11 (1), 221-241. Doi: 10.18074/ckuiibfd.813685. 


\section{Giriş}

Ülkeler çeşitli sosyal politika araçlarını kullanarak sosyal devlet olmanın gerektirdiği önlemleri uygulamaya koyarlar. Sosyal politika; devletin toplumun refahını yükseltmek ve sosyal koruma alanındaki hedeflerini yerine getirmek için başvurduğu araçlar bütünüdür (Hacımahmutoğlu, 2009). Bu araçlardan özellikle yoksullukla mücadele açısından önemli kamu enstrümanı olarak kabul edilen araç sosyal yardım politikalarıdır. Hükümetler yoksullukla mücadele etmek, gelir grupları arasındaki farkı azaltmak gibi amaçlar doğrultusunda sosyal yardım programlarından yararlanmaktadır. Uygulamadaki sosyal yardım programları ülkelerin siyasi ve sosyoekonomik özelliklerine göre değişiklik göstermektedir. Hak temelli yaklaşımı esas alan ülkeler sosyal yardımların gerekliliğini savunurken bu anlayışın dişındaki ülkeler sosyal yardım programlarına ayrılan bütçeleri kimi zaman bir yük olarak görebilmektedirler (Karagöl ve Dama, 2015). Kamu transferi yoluyla yoksul kesime aktarılan sosyal yardımlar, yardımlardan yararlanacak hanelerin objektif, adil ve tarafsız şekilde belirlenmesi halinde kamu bütçesine bir yük olmaktan çıkacaktır. Doğru hedef kitle belirlendiği durumda sosyal yardımların verimliliği ve yardımlar için sosyal destek de artacaktır (Daşlı, 2015).

Akademik yazında sosyal yardımlara ilişkin çalışmalar genel olarak sosyal yardım yoksulluk ilişkisine yöneliktir (Altındağ, 2019; Özdemir, 2019; Salduz ve Arslankoç, 2021). Sosyal yardımların yoksullukla ilişkisinin araştırılması gerekli olmakla birlikte sosyal yardım alıcılarının genel bir profilini çizmek ve hedef kitlenin ihtiyaçları doğrultusunda yardımlar gerçekleştirmenin de önemli olduğu düşünülmektedir. Literatürde sosyal yardımların belirleyicilerini analiz eden Gezer ve Gürler (2016), Gürler vd. (2017) gibi kısıtlı sayıda çalışma yer alırken; bu çalışmalarda sosyal yardımları oluşturulan bağımlı değişken sayısı sınırlıdır. $\mathrm{Bu}$ durum göz önüne alınarak daha tutarlı sonuçların elde edilmesi için araştırmamızda sosyal yardımları kapsayan değişken sayısı arttırılmıştır. Böylece bu çalışma ile Türkiye'de sosyal yardımların belirleyicileri hakkında yeni ampirik kanıtlar sunmak ve literatüre katkı sağlamak amaçlanmaktadır.

Çalışmada TÜİK'in 2002 yılından itibaren her yıl düzenli olarak yapmış olduğu hanelerin sosyoekonomik özellikleri, yaşam düzeyleri ve tüketim kalıpları hakkında bilgi veren 2003-2015 dönemi Hanehalkı Bütçe Anketi mikro veri setinden yararlanılmıştır. Dörder sene arayla karşılaştırılmalı olarak incelenebilmesi için 2003, 2005, 2011 ve 2015 yıllarında hanehalklarına yapılan, ayni ve nakdi yardımların toplamından oluşan sosyal yardımların sosyoekonomik belirleyicileri kantil regresyon yöntemiyle analiz edilmiştir.

Üç bölüm olarak tasarlanan çalışmanın ilk bölümünde; sosyal yardım kavramı, Türkiye'de sosyal yardım anlayışı ve uygulanan programlar hakkında genel bir çerçeve sunulmuştur. Çalışmanın ikinci bölümünde; sosyal yardımlara ilişkin literatür taramasına yer verilerek bu çalışmanın literatürdeki önemine dikkat 
çekilmiştir. Uygulama bölümü olan, çalışmanın üçüncü bölümünde ise; öncelikle bu araştırmada yararlanılan veri setinin yapısı, kullanılan değişkenler ve tanımlayıcı istatistiklere yer verilmiştir. Ardından uygulamada kullanılan ekonometrik yöntemlerden biri olan kantil regresyonun teorik yapısına ve kantil regresyon model sonuçlarına yer verilmiştir. Uygulama bölümünde ampirik analizden elde edilen bulgular yorumlanıp, değerlendirilmiş ve çalışma sonuç bölümü ile sonlandırılmıştır.

\section{Sosyal Yardımlar}

Sosyal yardımlar tarihsel gelişim içerisinde dini-kültürel değerler, aile, akrabalık ve komşuluk bağları gibi temellere dayanan gönüllülük ve hayırseverlik olgusu ile gerçekleştirilmiştir. Dini güdüler ve hayırseverlik anlayışı ile yürütülen yardımlar, daha sonra kamu aktörü olarak devlet tarafından uygulanmaya başlanmıştır (Türkoğlu, 2013). Türkiye'de sosyal politikaları devletin üstlenici rolü, 1961 Anayasası'ndaki sosyal bir hukuk devleti ilkesiyle net olarak temellendirilmiştir. Anayasal zeminde, sosyal devlet olma gerekliliği ve ihtiyaç sahibi bireylerin gereksinimlerinin telafi edilmesi bir hak olarak değerlendirilmiştir (Taşçı, 2017).

Sosyal devletin sosyal politika araçları ile toplumsal riskleri ve güvensizlikleri ortadan kaldıran, bireyin ve dolayısıyla toplumun refahını artıran, koruyucu ve güçlendirici rol üstlenen, sosyal adalet ve eşitliği sağlayan bir görev üstlenmesi beklenmektedir. Devletin sosyal politikalarından biri olan sosyal yardımlar; genel anlamda ihtiyaç sahibi bireyleri ekonomik ve sosyal risklere karş1, ayni (nesnel) ve nakdi (parasal) karşılıksız şekilde destek sağlayarak ihtiyaçlarını karşılama amacı taşıyan uygulamalardır. Sosyal politikalar içerisinde sosyal güvenlik sisteminin yetersiz olduğu durumlarda tamamlayıcı rol üstlenen sosyal yardımlar, ilk olarak sosyal güvencesi olmayan kesime uygulanmaktadır. Sosyal yardımlar, yararlanıcıların herhangi bir katkısı olmadığı için kamu yardımları veya karşılıksız transferler şeklinde de adlandırılmaktadır (Taşçı, 2007).

Literatürde sosyal yardım harcama kaleminin gayrisafi yurtiçi hasıladaki (GSYH) payı, sosyal devlet etkinliğinin bir göstergesi olarak ifade edilmektedir. Bilimsel değerlendirmeler, genellikle sosyal devletlerin (sosyal programlarının cömertliğinin bir göstergesi olarak) kamu harcamalarının GSYH yüzdesine odaklanır (Pacek ve Freeman, 2017). Sosyal harcamalara ayrılan kaynağın GSYH'ye oranının artması sosyal devlet olmanın göstergesi olarak nitelendirilmektedir. Ancak sayısal olarak sosyal harcamaların artmasının yeterli olmayıp niteliğinin de artması gerekmektedir (Esping-Andersen, 1990).

Sosyal yardımlar nicelik olarak artmakla birlikte neo-liberal politikalara bağlı olarak zedelenmesi, ekonomik ve sosyal yaşamdaki etkinliğinin zayıflaması, ar-ge faaliyetlerinin yetersizliği, istihdam olanaklarının kısıtlı olması gibi sorunlar nedeniyle yeterli bulunmamaktadır. Sosyal yardımların niceliği artarken 
niteliğinin artmaması, yoksulluğun kuşaklar arası aktarımına sebep olmaktadır (Daşl1, 2015).

\subsection{Türkiye'de Sosyal Yardım Anlayışı}

Türkiye'de sosyal devlet olma prensibi, 1961 Anayasa sürecine bağlı olarak, sosyal politikaların ve sosyal politikaların önemli araçlarından biri olan sosyal yardımların önemli araçlarından biri olan sosyal yardımların sosyal politikaların devlet eliyle uygulamaya konulmasını beraberinde getirmiştir. Kronolojik sıra ile bu prensipleri yerine getirme hususunda mevzuatın içerisinde:

Türkiye'de ilk sosyal yardım uygulaması olarak kabul edilen düzenleme, 2022 sayılı 65 Yaşını Doldurmuş Muhtaç, Güçsüz ve Kimsesiz Türk Vatandaşlarına Aylık Bağlanması Hakkında Kanun 1 Temmuz 1976'da çıkarılan kanundur. 1983 yılında 2828 sayılı Kanunla kurulan Sosyal Hizmetler ve Çocuk Esirgeme Kurumu Genel Müdürlüğü günümüzde AÇSHB bünyesinde Çocuk Hizmetleri Genel Müdürlüğü olarak faaliyetini sürdürmektedir. Bu kurumun görevi kısaca; çocuk evleri sitesi, çocuk evi ve çocuk destek merkezi olarak hizmet vermektir (Şirin, 2021). Yoksullukla mücadele etmede önemli bir adım, 29 Mayıs 1986 tarihinde 3294 sayılı Sosyal Yardımlaşma ve Dayanışmayı Teşvik Kanunun kabul edilmesi ve Sosyal Yardımlaşma ve Dayanışmayı Teşvik Fonunun (SYDTF) kurulması ile atılmıştır. Yoksul kesim içerisinde sosyal güvenlik kurumuna kayıtlı olmayan Türk vatandaşlarına sağlık hizmetinden yararlanabilmeleri için 18 Haziran 1992 tarihinde 3816 sayılı Ödeme Gücü Olmayan Vatandaşların Tedavi Giderlerinin Yeşil Kart Verilerek Devlet Tarafından Karşılanması Hakkında Kanun ile 3 Temmuz 1992 tarihinde Yeşil Kart ${ }^{3}$ uygulaması yapılmıştır (Şişman, 2017).

2001 yılında Dünya Bankası tarafından sağlanan mali destek ile Sosyal Riski Azaltma Projesi (SRAP) uygulamaya konulmuştur. ${ }^{4}$ SRAP kapsamında 2003 yılında Ankara, Çankırı, Gaziantep, Sinop, Kahramanmaraş, Zonguldak illerinde pilot uygulama ile başlayan Şartlı Nakit Transferi 2004 yılından itibaren tüm bölgelerde uygulanmıştır (Esenyel, 2009). Bir diğer uygulama ise Başbakanlık sekreterlik bölümünde faaliyet gösteren SYDTF, 9 Aralık 2004 tarihinde Sosyal Yardımlaşma ve Dayanışma Genel Müdürlüğü (SYDGM) olarak kurumsal yapıya dönüşmesi olmuştur. (Bakan ve Özdemir, 2012). 2005 yılından yürürlüğe giren 5393 sayılı Belediye Kanunu ile il özel idarelerine ve belediyelere de sosyal yardım yapma yetkisi verilmiştir.

\footnotetext{
${ }^{3} 1$ Ocak 2012 tarihi itibariyle Genel Sağlık Sigortası başlatılmıştır.

${ }^{4} 2007$ 'den itibaren projenin finansal kaynağını Türkiye sağlamaktadır. Günümüzde Aile Çalışma ve Sosyal Hizmetler Bakanlığı bünyesinde Sosyal Yardımlar Genel Müdürlüğü tarafından yürütülen sosyal yardımlar büyük ölçüde SRAP'la şekillenmiştir.
} 
Sosyal politikaların tek çatı altında toplanması ve sosyal yardımların kurumsal yapıya dönüşmesi adına 2011 yılında Aile ve Sosyal Politikalar Bakanlığı (ASPB) kurulmuştur. 9 Temmuz 2018 tarihinde ASPB ile Çalışma ve Sosyal Güvenlik Bakanlığı, Çalışma Sosyal Hizmetler ve Aile Bakanlığı adı altında birleştirilmiştir. 4 Ağustos 2018 itibariyle Resmî Gazete' de yayımlanan Cumhurbaşkanlığı kararnamesi ile ismi tekrar değiştirilerek Aile, Çalışma ve Sosyal Hizmetler Bakanlığı (AÇSHB) olmuştur (SYGM, 2020). 21 Nisan 2021 tarihinde resmî gazetede yer alan bir kararname ile bakanlık ikiye bölünerek Türkiye Cumhuriyeti Aile ve Sosyal Hizmetler Bakanlığı olarak değiştirilmiştir (ASHB, 2021).

Sosyal yardımların oluşumunun tarihsel sürecine bakıldığında yardımlaşma ve dayanışma ilk olarak hayırseverlik, akrabalık bağları gibi bireysel ilişkiler üzerinden ortaya çıkarken sonraları çeşitli hayır kurumları ve vakıflar aracılığıyla daha organize bir yapı kazanmıştır. İlerleyen süreçte sosyal yardımların Anayasa'da yer almasıyla birlikte devlet nazarında çeşitli uygulamalar yürürlüğe girmiştir. Sosyal yardımların kurumsal yapıya dönüşmesi adına önemli adımlardan biri Aile ve Sosyal Hizmetler Bakanlığı olmakla birlikte sosyal politikalarda faaliyet gösteren Bakanlığın isminin Aile ve Sosyal Hizmetler Bakanlığı olması aile aktörüne de önem verildiğini doğrular niteliktedir. Sosyal yardımdan yararlanma koşullarından bakacak kimsesi (aile, akraba vb.) olmayan ibaresinin yer alması öncelikli sorumluluğun devlette değil aileye düştüğüne işaret etmektedir. $\mathrm{Bu}$ durum sosyal yardım sisteminin anayasal düzlemde belirtilen sosyal hak temelli kurumsallaşmasını önemli ölçüde engellemektedir (Taşçı, 2017; Ulutaş, 2017).

Sosyal yardımlara olan ihtiyaç; hanelerin demografik özelliklerine, siyasi yönelimlerine ve yetkililere karşı güvenlerine bağlı olarak farklılık göstermektedir (Buğra ve Keyder, 2005). Halbuki sosyal yardımlar ile tüm hanelerin ve bireylerin 1rk, cinsiyet, dil ve din ayrımı yapılmaksızın hak mahrumiyetlerinin ortadan kaldırılması, sosyal dışlanmanın önlenmesi, kırılgan grubun marjinalleşmesinin önüne geçilmesi gerekmektedir. Devlet ve birey arasında bir hak bağlamı söz konusu olması, ihtiyaç sahibi kitlenin toplumun farklı kesimleri ile eşit ve bu toplumun bir parçası olunduğuna dair aidiyet hissinin oluşturulması açısından önem arz etmektedir.

\section{Literatür Araştırması}

Sosyal yardımlarla ilgili yapılan çalışmalar, sosyal yardımların yoksulluk ile ilişkisi üzerine yoğunluk göstermektedir. Sosyal yardımların yoksulluğu önlemede önemli bir araç olması araştırmaların bu yönde ilerlemesine neden olmuştur. $\mathrm{Bu}$ bağlamda sosyal yardımların yoksulluk ile ilişkisi üzerine literatür incelendiğinde sosyal yardımları etkileyen bazı değişkenler dikkat çekmektedir. Özellikle sosyal yardımların cinsiyet temelli olarak daha çok yapıldığı, bu durumun kadının toplum içindeki sosyoekonomik statüsünden ve devlet destekli olarak uygulanan kadınlara yönelik pozitif ayrımcılıktan kaynaklandığı düşünülmektedir. Bir diğer 
önemli değişken olan medeni durum açısından bakıldığı zaman; bekâr bireylere daha fazla sosyal yardım yapıldığı ve eğitim seviyesi arttıkça sosyal yardımlardan memnuniyet düzeyinin azalmasıdır. Bu neticeler doğrultusunda sosyoekonomik faktörlerin sosyal yardımları nasıl etkilediğinin belirlenmesi önem arz etmektedir. $\mathrm{Bu}$ nedenle çalışmada sosyal yardım alan hanelere ait sosyoekonomik faktörlerin sosyal yardım alma üzerine etkisi araştırılmıştır. Literatüre ait bazı çalışmalar özet halinde Tablo 1'de yer almaktadır.

\section{Tablo 1: Seçili Ampirik Literatür}

\begin{tabular}{|c|c|c|c|c|}
\hline Yazar(lar) & Ülke & $\begin{array}{l}\text { Veri Seti ve } \\
\text { Dönemi }\end{array}$ & Yöntem & $\begin{array}{l}\text { Kullanılan } \\
\text { Açıklayıcı } \\
\text { Değişkenler }\end{array}$ \\
\hline $\begin{array}{l}\text { Datt, Simler, } \\
\text { Mukherjee ve } \\
\text { Dava (2000) }\end{array}$ & Mozambik & $\begin{array}{l}\text { 1997-1999, Ulusal } \\
\text { Hanehalkı Yaşam } \\
\text { Standart }\end{array}$ & $\begin{array}{l}\text { En Küçük } \\
\text { Kareler } \\
\text { Yöntemi } \\
(\text { EKK) }\end{array}$ & $\begin{array}{l}\text { Eğitim durumu, } \\
\text { doğurganlık, bağımlı } \\
\text { nüfüs }\end{array}$ \\
\hline $\begin{array}{l}\text { Mukherjee ve } \\
\text { Benson (2003) }\end{array}$ & Malavi & $\begin{array}{l}\text { 1997-1998, } \\
\text { Entegre Hanehalk1 } \\
\text { Anketi }\end{array}$ & EKK & $\begin{array}{l}\text { Eğitim durumu, } \\
\text { cinsiyet, çalışılan } \\
\text { sektör. }\end{array}$ \\
\hline $\begin{array}{l}\text { Geda, Jong, } \\
\text { Mwangi ve } \\
\text { Mwabu (2005) }\end{array}$ & Kenya & $\begin{array}{lr}1994, & \text { Hanehalk1 } \\
\text { Bütçe } & \text { Anketi } \\
\text { (HBA) } & \\
\end{array}$ & Logit & $\begin{array}{l}\text { Eğitim durumu, } \\
\text { hanehalk1 büyüklüğü, } \\
\text { çalışılan sektör }\end{array}$ \\
\hline $\begin{array}{l}\text { Pashardes ve } \\
\text { Polycarpou } \\
(2011) \\
\end{array}$ & $\begin{array}{l}\text { Güney } \\
\text { Kibris }\end{array}$ & $\begin{array}{l}\text { 2005-2008 Gelir ve } \\
\text { Yaşam Koşulları } \\
(\mathrm{GYK})\end{array}$ & EKK & $\begin{array}{l}\text { Medeni durum, eğitim } \\
\text { durumu, cinsiyet }\end{array}$ \\
\hline Cafrı (2009) & $\begin{array}{l}\text { Adana, } \\
\text { Türkiye }\end{array}$ & 2008, TÜBİTAK & Probit, Tobit & $\begin{array}{l}\text { Yaş, kadın birey sayısı, } \\
\text { eğitim, medeni durum }\end{array}$ \\
\hline $\begin{array}{l}\text { Canbay ve Selim } \\
(2010)\end{array}$ & Türkiye & $2004, \mathrm{HBA}$ & Logit & $\begin{array}{l}\text { Hanehalk1 büyüklüğü, } \\
\text { hanehalk1 reisinin; } \\
\text { yaşı, eğitim durumu }\end{array}$ \\
\hline $\begin{array}{l}\text { Aydın ve } \\
\text { Güloğlu (2011) }\end{array}$ & Türkiye & 2003-2006, HBA & $\begin{array}{l}\text { Varyans } \\
\text { Analizi }\end{array}$ & $\begin{array}{l}\text { Hane reisinin cinsiyeti, } \\
\text { eğitim durumu }\end{array}$ \\
\hline $\begin{array}{l}\text { Tatlıdil ve } \\
\text { Demirağ (2014) }\end{array}$ & Türkiye & 2009, GYK & Logit & $\begin{array}{l}\text { Hanehalkı büyüklüğü, } \\
\text { mülkiyet durumu, } \\
\text { hanehalkı reisinin yaşı, } \\
\text { eğitim durumu }\end{array}$ \\
\hline $\begin{array}{l}\text { Gezer ve } \\
\text { Birecikli (2016) }\end{array}$ & Türkiye & $2010, \mathrm{HBA}$ & $\begin{array}{l}\text { Kesikli } \\
\text { EKK, } \\
\text { Probit, Tobit }\end{array}$ & $\begin{array}{l}\text { Yaş, eğitim durumu, } \\
\text { hanehalkı büyüklüğü }\end{array}$ \\
\hline $\begin{array}{l}\text { Gürler, Emeç ve } \\
\text { Birecikli (2017) }\end{array}$ & Türkiye & 2003-2013, HBA & Probit,Tobit & $\begin{array}{l}\text { Yaş, cinsiyet, hhb, } \\
\text { medeni durum }\end{array}$ \\
\hline $\begin{array}{l}\text { Sigeze ve Şengül } \\
(2018)\end{array}$ & Türkiye & 2009-2012, GYK & $\begin{array}{l}\text { Multinomial } \\
\text { Logit Model }\end{array}$ & $\begin{array}{l}\text { Hanehalkı reisinin ve } \\
\text { eşinin eğitim durumu, } \\
\text { bağımlı çocuk sayısı }\end{array}$ \\
\hline
\end{tabular}

Kaynak: Yazarlar tarafindan oluşturulmuştur.

Türkiye'de sosyal yardımların belirleyicilerini mikro düzeyde inceleyen ampirik çalışmalar sınırlı sayıdadır. Bu çalışmada sosyal yardımları analiz eden kısıtlı çalışmalardan farklı olarak sosyal yardım miktarına etki eden faktörlerin etkisi 
araştırılmıştır. Kantil regresyon yöntemi; sosyal yardım miktarının çeşitli kantillerine bağlı olarak farklı sonuçların tahmin edilebilmesine olanak sağlamaktadır ve çalışmanın bu yönüyle literatüre katkı sağlayacağı düşünülmektedir.

\section{Araştırma Metodolojisi}

\subsection{Veri Seti}

Çalışmada yararlanılan veriler Türkiye İstatistik Kurumu'nun hazırladığı Hanehalkı Bütçe Araştırması Mikro Veri Seti çalışmalarından derlenmiştir. Türkiye genelinde 2002 yılından itibaren her yıl düzenli olarak gerçekleştirilen hanehalkı bütçe anketi, örnekleme tekniklerine göre belirlenen ve her ay farklı hanehalklarına 1 Ocak-31 Aralık tarihleri arasında hedef yıl için uygulanmaktadır. Hanehalkı bütçe anketi; hanehalklarının yaşam düzeyleri, yoksulluk sınırının belirlenmesi, ayni-nakdi gelirleri ve sosyoekonomik göstergelerini (yaş, cinsiyet, eğitim durumu vb.) analiz etmek için gerekli verilerin sağlanması amaciyla uygulanmaktadır. Hanehalkı; aralarında herhangi bir akrabalık bağı olsun olmasın aynı konutta veya aynı konutun bir kısmında ikamet eden, gelir ve giderlerini ayırmayan, temel gereksinimlerini birlikte karşılayan, hanehalkı hizmet ve yönetimine katılan bir veya birden fazla bireyin oluşturduğu topluluktur. Hanehalkı reisi; hanehalkının gelir ve giderlerinin yönetiminden sorumlu, hanenin mensubu olan tüm bireylerin özellikleri hakkında optimal bilgiye sahip olan ve temsil ettiği hanehalkı adına hukuki, iktisadi ve sosyal tasarrufta bulunabilen kişidir. Hanedeki referans kişi ise en yüksek gelire sahip olan ferttir (TÜİK, 2015). Hanehalkı bütçe anketinde yardım; ihtiyaçlarını karşılamada yetersiz olan hanehalklarının bütçesine katkı sağlamak amacıyla yapılan mal ve hizmetler olarak tanımlanmaktadır (TÜİK, 2008).

Çalışmada sosyal yardım bağımlı değişkeni, yıllık olarak hanedeki bütün bireylere yapılan nakdi ve ayni yardımların toplamı olarak belirlenmiştir. Hanehalkı bütçe anketi fert veri setinde yer alan on değişken ayni ve nakdi sosyal yardımlar bağımlı değişkenini oluşturmuştur. Hedef kitleye SYDTF gibi kurum ve kuruluşlar tarafından sağlanan nakdi yardımlar: Yıllık yaşlılık maaşı, yıllık sosyal yardım fonu ve aile yardımı, yıllık dul, yetim, öksüz maaşı, yıllık gazilik ve malullük maaşı, hastalık yardımı, yıllık öğrenci burs geliri, özel kişi ve kurumlardan elde edilen nafaka, yardım, burs vb. şeklinde yıllık nakdi gelir, yurt dışından karşılıksız elde edilen döviz, yardım, burs vb. şeklinde yıllık nakdi gelir ve ayni yardımlar: Devletten elde edilen yıllık ayni gelir, yurt dışından elde edilen yıllık ayni gelir, özel kişi ve teşebbüslerden elde edilen yıllık ayni gelirdir.

Bağımsız değişkenler; fert ve hane veri seti değişkenlerinden elde edilmiştir. Hanehalkı reisine ait cinsiyet, yaş, eğitim durumu, medeni durum ve çalışma durumu değişkeni, hane veri setinden ise mülkiyet durumu değişkeni kullanmıştır. 
Demografik özelliklerden; yaş değişkeni 15-19, 20-29, 30-39, 40-49, 50-59, 6064,65 ve üstü şeklinde yedi sıralı değişken olarak oluşturulmuştur.

Bireyin eğitim durumu; okur-yazar değil/okul bitirmedi, ilkokul ve ortaokul mezunu, lise mezunu, yüksekokul-fakülte ve lisansüstü olarak beş grup olacak şekilde uygulamada kullanılmıştır. Bir başka değişken olan medeni durum; evli ve bekâr (hiç evlenmedi, boşandı, eşi öldü) şeklinde iki kategoriye ayrılarak uygulamada yer almıştır. Fert veri setinden alınan çalışma durumu, çalışmıyor ve çalışıyor şeklinde ikili kategorik değişken olarak oluşturulmuştur. Sosyal yardım alan bireylerin konut sahibi olup olmadığı da uygulamada kukla değişken olarak kullanılan bir diğer değişkendir.

Tablo 2: Değişkenlere Ait Açıklayıcı Bilgiler

\begin{tabular}{lcrrrrrrr}
\hline YIL & \multicolumn{2}{c}{$\mathbf{2 0 0 3}$} & \multicolumn{2}{c}{$\mathbf{2 0 0 7}$} & \multicolumn{2}{c}{$\mathbf{2 0 1 1}$} & \multicolumn{2}{c}{$\mathbf{2 0 1 5}$} \\
\hline Değişkenler & Ort. & \multicolumn{1}{c}{ S.S. } & Ort. & S.S. & Ort. & S.S. & Ort. & \multicolumn{1}{c}{ S.S. } \\
\hline Cinsiyet & 0.904 & 0.293 & 0.892 & 0.309 & 0.87 & 0.335 & 0.860 & 0.346 \\
\hline Eğitim Durumu & 1.233 & 0.798 & 1.238 & 0.802 & 1.332 & 0.894 & 0.831 & 0.373 \\
\hline Yaş & 4.299 & 1.47 & 4.316 & 1.452 & 4.434 & 149 & 4.626 & 1.51 \\
\hline Medeni Durum & 0.920 & 0.468 & 0.924 & 0.505 & 0.853 & 0.354 & 1.903 & 0.840 \\
\hline Ayni Yardım & 30 & 268 & 63.9 & 334.7 & 186.0 & 870 & 63.77 & 320 \\
\hline Nakdi Yardım & 292.8 & 1015 & 383.4 & 1430 & 1700 & 416 & 2395 & 5200 \\
\hline Harcama & 698.1 & 625 & 1300 & 994.1 & 2076 & 166 & 2879 & 2718 \\
\hline HHB & 4.176 & 2.04 & 4.049 & 1.997 & 3.743 & 194 & 3.564 & 1.903 \\
\hline Gelir & 1014 & 1147 & 1773 & 1564 & 2697 & 257 & 3766 & 3673 \\
\hline Ayni OECD & 15.88 & 151 & 32.99 & 186.8 & 100.3 & 503 & 31.31 & 160.5 \\
\hline Nakdi OECD & 167.1 & 660 & 236.6 & 982.6 & 958.7 & 255 & 1418 & 3435 \\
\hline Toplam Yardım & 182.9 & 679 & 2696 & 1008 & 1059. & 266 & 1449 & 3443 \\
\hline Gözlem & 25763 & \multicolumn{4}{c}{8548} & 9916 & 11491 \\
\hline
\end{tabular}

Kaynak: Yazarlar tarafından oluşturulmuştur.

Çalışmada kullanılan örneklem büyüklügü 55718 hanedir. Analiz yapılırken veri setinin sahip olduğu hanehalklarının her birine ait örneklem ağırlıklandırılması olan faktör değişkeni ile ağırlıklandırma yapılmıştır. Tablo yıllar itibariyle genel olarak incelendiğinde; yaklaşık ortalama \%88'inin erkek, yaş ortalamasının 49-55 yaş aralığında, eğitim seviyesinin ortalama olarak ilkokul veya ortaokul dengi mezunu olduğu ve bunların yaklaşık ortalama \%89'unun evli olduğu gözlemlenmektedir. 2011 yılındaki ayni yardım miktarında diğer yıllara göre ciddi bir artış yaşandığı, nakdi yardımların ise ilgili yıllara takiben arttığ görülmektedir. Söz konusu yıllar için harcama değişkeni artış sergilerken, hanehalkı büyüklüğü ortalama 3-4 kişi olarak değişmektedir. Ayni ve nakdi yardımların toplamından oluşan sosyal yardımların ilgili yıllarda artan bir seyir izlediği gözlemlenmiştir. 


\subsection{Kantil Regresyon Yöntemi}

Regresyon analiz; genellikle bağımsız değişken ve bağımlı değişken arasındaki bağlantıyı analiz etmek için kullanılan bir yöntemdir. Geleneksel en küçük kareler yöntemi, regresyon dağılımının merkezinde yer alan koşullu medyan ve koşullu ortalamayı yaklaşık olarak hesaplamaya olanak sağlar. Bu tür ortalama tabanlı tahmin ediciler veri dağılımının tamamını temsil etmede yetersizdir (İpek ve Sekmen, 2017). Doğrusal regresyon modeli sosyal bilimlerde sıkça kullanılan standart bir istatistiksel modeldir. Ancak yöntem bir yanıt değişkeni olan bağımlı değişkenin koşullu ortalamasını modellemeye odaklanır, bağımlı değişkenin tam koşullu dağılım özelliklerini hesaplayamaz. Koenker ve Bassett (1978) tarafından önerilen kantil regresyon; bağımlı değişkenin tam koşullu dağılım özelliklerinin analizine olanak sağlar. Medyandan daha genel bilgi sunan kantil regresyon, birçok bağımsız değişken ve bir bağımlı değişken arasındaki ilişkinin hem konum değişimlerini hem de şekil değişimlerini modeller. Kantil regresyon bir değiş̧kenin koşullu dağılımdaki çeşitli nicelikler üzerindeki potansiyel diferansiyel etkisini, örneğin, 0,05'inci ve 0,95'inci kantilden 19 eşitlikte eşitlenmiş kantillerin bir dizisini tahmin eder. Medyan ve kantillerle, bu 19 yerleştirilmiş regresyon çizgisi, yer değişimini (medyan çizgisi), ölçek ve daha karmaşık şekil kaymalarını (medyan kantiller çizgileri) analiz eder. $\mathrm{Bu}$ şekilde, kantil regresyon bir değişkenin tam dağılım üzerindeki farksal etkisini tahmin eder ve uç değerleri dikkate alır (Hao ve Naiman, 2007).

Kantil regresyonun en küçük kareler yöntemi ile önemli farklılıkları bulunmaktadır. Klasik regresyon koşullu regresyon hakkında bilgi verirken, kantil regresyon bağımlı değişkenin tüm koşullu dağılımı üzerinde bakış açısı sunar. En küçük kareler tahminindeki kareleri minimize etmenin aksine artıkların mutlak değerlerinin ağırlıklı toplamını minimize eden nicel regresyon tahminidir. Kantil regresyon monoton denklik ve şartlı niceliklerdeki dağılım varsayımlarına karş1 dayanıklıdır. En küçük kareler yöntemi, doğrusal regresyon gibi geleneksel modeller daha yaygın kullanılsa da kantil regresyon kısıtlayıcı varsayımlara dayanmaz ve dağılım hakkında daha fazla bilgi sunar (Hao ve Naiman, 2007). Bir değişkenin koşulunu tahmin etmek için kullanılan kantil regresyon yöntemi, farklı kantillerde bağımlı değişkenin farklı tepkiler üretme potansiyeline sahiptir. $\mathrm{Bu}$ farklı tepkiler; bağımlı değişkenin koşullu dağılımında yer alan çeşitli noktalarındaki değişiklerle karşı, bağımsız değişkenin tepkisindeki farklılıklar olarak yorumlanabilir (Çağlayan ve Astar, 2012).

Kantil regresyon, koşullu kantil fonksiyonlarının tahmini hedeflerini genişletir. Bağımlı değiş̧kenin koşullu dağılımının kantil modelleri, orta değişkenin fonksiyonu olarak ifade edilir. Kantil regresyon, koşullu kantil fonksiyonu için tahmin modellerine eşit olarak uygun metot sağlar. Kantiller genellikle örnek gözlemleri tanımlamak için kullanılır (Koenker ve Hallock, 2001). Koşullu kantil fonksiyonu için doğrusal ve doğrusal olmayan yanıt modelleri istatistiksel analizi 
kapsamlı bir yaklaşımdır. Kantil regresyon rassal değişkenler arasında olasılıksal ilişkilerin daha eksiksiz istatistiksel analizini sağlama yeteneğine sahiptir (Xiao ve Koenker, 2002). Koşullu kantil fonksiyonları tek değişkenli koşullu dağılımlar hakkında gözlemlenebilen her şeyi tamamen ortaya koyabildiği için yapısal modellerin doğal yapı taşını oluşturur. Kantil regresyon, parametrik olmayan yapısal modeller için temel niteliğindedir. Veri kaynakları zenginleştikçe ve heterojenliğin öneminin farkındalığı arttıkça kantil regresyon daha önemli hale gelmiştir (Koenker, 2017).

Kantil regresyon modeli; belirli x için y’nin tüm koşullu dağılımını tahmin etmek için bir olanak sağlar. Daha fazla kantil regresyon değeri daha fazla bilgi verme potansiyeline sahiptir (Buchinsky, 1994). Kantil regresyon, hanehalklarına ait demografik değişkenlerin bağımlı değişken olan sosyal yardım miktarının çeşitli kantillerine bağlı olarak farklı sonuçların tahmin edilebilmesine olanak sağlamaktadır. İstenilen her kantil seviyesi için tahmin değerleri elde edilebilir. Çalışmada, literatürde sıklıkla tercih edilen 10., 25., 50., 75., 90. kantiller için regresyon tahminleri yapılmıştır.

Koenker and Bassert (1978) tarafindan tanımlanan kantil regresyon modelinde, her bir $\theta$. kantil için Denklem 1'de gösterilen problemi $0<\theta<1$ aralığında minimize eder.

$$
\min _{b \in R^{K}}\left[\sum_{t \epsilon\left(t: y_{t}>x_{t} b\right)} \theta\left|y_{t}-x_{t} b\right|+\sum_{t \epsilon\left(t: y_{t}<x_{t} b\right)}(1-\theta)\left|y_{t}-x_{t} b\right|\right]
$$

Burada; $\theta$ tahmin edilecek kantil iken, $\left\{x_{t}: \mathrm{t}=1, \ldots, \mathrm{K}\right\} \mathrm{K}$ boyutlu açıklayıcı değişkenler matrisi $\left\{y_{t}: \mathrm{t}=1, \ldots, \mathrm{T}\right\}$ çıtı değişkenidir. Regresyon modelindeki rassal örneklemi temsil ederken $u_{t}=y_{t}-x_{t} \beta$ dağılım fonksiyonudur.

Mutlak sapmaların ağırlıklandırılmış toplamı, pozitif sapmalar için ( $\theta)$ ağırlığı, negatif sapmalar için (1- $\theta$ ) ağırlığı kullanılır (Furno ve Vistocco, 2018). Klasik regresyonun yanı sira kantil regresyon; lineer modeller parametre tahminleri değişim oranını: $\beta(\theta)$ katsayısı göstergelerin değeri bağımsız değişkenin birim başına değişimin $\theta$. kantilin değişim oranı olarak yorumlanabilir. Kantil regresyon, bağımlı değişskenin tüm koşullu dağılımı üzerinde bilgi sunar (Davino, Furno ve Vistocco, 2013).

\section{Bulgular ve Tartışma}

Çalışmada kantil regresyon modeli kullanılarak yaş, cinsiyet, medeni durum, eğitim durumu gibi bağımsız değişkenlerin sosyal yardım alma üzerine etkileri 2003-2015 dönemi için araştırılmıştır. Karşılaştırılmalı olarak incelenebilmesi için 2003, 2007, 2011 ve 2015 yıllarına ait sonuçlara yer verilmiştir ${ }^{5}$. Oluşturulan

\footnotetext{
${ }^{5}$ Çalışmada yer verilmeyen yıllara ait analiz sonuçları yazarlardan temin edilebilir.
} 
ekonometrik model üzerinden sosyal yardımın aldığı katsayı değerleri ve model tahmin sonuçları yıllara göre tablolarda gösterilmiştir.

2003 y1lı için kantil regresyon tahmin sonuçlarına Tablo 3'te yer verilmiştir. Bu sonuçlara göre cinsiyet değişkeni incelendiğinde, katsayı tahminleri bütün kantiller için istatistiksel olarak anlamlı ve negatiftir. Yani kadınların erkeklerden daha fazla sosyal yardım aldığı görülmektedir. Yaş değişkeni katsayı tahminleri 0.90 'ıncı kantil değeri dışında \%1 anlamlılık seviyesine göre anlamlı ve pozitiftir. $\mathrm{Bu}$ tahminlere göre bireyin yaşı ile sosyal yardım alma durumu arasında doğru yönlü ilişki vardır. Bireyin yaşı arttıkça daha fazla sosyal yardım almaktadır. Eğitim durumu katsayı işaretleri pozitiftir. Katsayı tahminleri farklı anlamlılık düzeylerinde istatistiksel olarak anlamlı ve pozitiftir. Dolayısıyla eğitim durumunun sosyal yardım alma üzerinde etkisi vardır. Eğitim durumu arttıkça alınan sosyal yardımların arttığı görülmektedir.

Tablo 3: 2003 Yılı Model Tahmin Sonuçları

\begin{tabular}{lrrrrr}
\hline Değişkenler & Q10 & Q25 & Q50 & Q75 & Q90 \\
\hline Cinsiyet & $-160.1^{* * *}$ & $-737.1^{*}$ & $-1344.4^{*}$ & $-1772.2^{*}$ & $-2169.7^{*}$ \\
\hline Yaş & $7.790^{*}$ & $19.601^{*}$ & $39.604^{*}$ & $65.196^{*}$ & 35.241 \\
\hline Ĕgitim Durumu & $1.835^{* * *}$ & $6.847^{* * *}$ & $21.460^{* *}$ & $157.1^{*}$ & $240.3^{*}$ \\
\hline Medeni Durum & -3.254 & -4.961 & $-16.634^{*}$ & -25.507 & $66.341^{*}$ \\
\hline Çalışma Durumu & $-15.388^{*}$ & $-66.121^{*}$ & $-158.9^{*}$ & $-347.4^{*}$ & $-423.5^{*}$ \\
\hline Konut Sahibi & $2.7666^{* * *}$ & $15.579^{*}$ & $56.528^{*}$ & $121.7^{*}$ & $192.3^{*}$ \\
\hline HHB & $-4.5587^{*}$ & $-12.320^{*}$ & $-37.893^{*}$ & $-66.679^{*}$ & $-119.2^{*}$ \\
\hline Toplam Harcama & $-0.00116^{*}$ & 0.0080 & $0.0959^{*}$ & $0.3137^{*}$ & $0.7238^{*}$ \\
\hline \multicolumn{4}{c}{ Not: ${ }^{* * *},{ }^{* * *}$ sirasiyla \% $10, \% 5, \% 1$ anlamlılık seviyelerini ifade etmektedir. }
\end{tabular}

Medeni durum için anlamlı çıkan göstergeler; 0.50'inci kantil değerinde anlamlı ve negatif, 0.90'ıncı kantil değerinde ise anlamlı ve pozitiftir. Diğer kantil değerleri için anlamsız olduğu belirlenmiştir. Anlamlı bulunan sonuçlar doğrultusunda; bekâr (hiç evlenmedi, dul, boşanmış) bireylerin evli bireylerden daha fazla sosyal yardım aldığı sonucu ortaya çıkmaktadır.

Çalışma durumu incelendiğinde tüm kantil değerleri için katsayı tahminleri \%1 anlamlılık seviyesinde anlamlı ve negatif çıkmıştır. Bir işte çalışmayan bireyler, çalışan bireylere göre daha fazla sosyal yardım almaktadır. Konut sahibi olma durumunda katsayı tahminleri tüm kantiller için anlamlı ve pozitiftir. Mülkiyet sahibi olan bireylerin, olmayanlara göre daha fazla sosyal yardım aldığı görülmektedir. Hanehalkı büyüklügü istatistiksel olarak tüm kantil değerleri için $\% 1$ anlamlılık düzeyinde anlamlı ve negatiftir. Hanehalkındaki birey sayısı arttıkça daha az sosyal yardım alındığı sonucuna ulaşılmaktadır. Toplam harcama değişkeni 0.25 'inci kantil değeri dışında anlamlıdır ve 0.10 'uncu kantil değeri (negatif) dışında pozitiftir. Anlamlı sonuçlara göre toplam harcama ile sosyal yardım arasında doğru yönlü bir ilişki vardır. 
2007 yılı katsayı tahminlerinin test istatistikleri Tablo 4 incelendiğinde cinsiyet değişkeni bütün kantiller için $\% 1$ anlamlılık seviyesinde anlamlı ve negatiftir. Kadınlardan erkeklere geçerken sosyal yardım miktarının azaldığı görülmektedir. Sonuçlara göre; yaş değişkenin katsayı tahmini tüm kantil değerleri için \%1 anlamlılık seviyesinde anlamlı ve pozitiftir. Bireyin yaşı ilerledikçe daha fazla sosyal yardım almaktadır. Eğitim değişkenine bakıldı ğında 0.90'ıncı kantil değeri (pozitif) dışında negatiftir. 0.75'ıncı kantil değeri dişında \%5 ve \%1 anlamlılık düzeylerinde anlamlı sonuçlar elde edilmiştir. Anlamlı kantil değerlerine göre eğitim sosyal yardım almayı negatif yönde etkilemektedir.

Tablo 4: 2007 Yılı Model Tahmin Sonuçları

\begin{tabular}{|c|c|c|c|c|c|}
\hline Değişkenler & Q10 & Q25 & Q50 & Q75 & Q90 \\
\hline Cinsiyet & $-59.815^{*}$ & $-220.1^{*}$ & $-533.2 *$ & $-1138.4 *$ & $-1375.2 *$ \\
\hline Yaş & $4.162 *$ & $12.950 *$ & $42.612 *$ & $58.844 *$ & $93.449 *$ \\
\hline Ĕgitim Durumu & $-1.435 * *$ & $-4.4446 *$ & $-9.654 * *$ & -13.135 & $100.1 * *$ \\
\hline Medeni Durum & $-77.174^{*}$ & $-638.1 *$ & $-1629.1 *$ & $-2417.1 *$ & $-2669.1 *$ \\
\hline Çalışma Durumu & 0.5831 & $-6.443 *$ & $-74.085 *$ & $-306.3 *$ & $-953.2 *$ \\
\hline Konut Sahibi & $1.899 * * *$ & $4.541 *$ & 9.2666 & $66.817 *$ & $142.2 * *$ \\
\hline HHB & $-3.119 *$ & $-5.646^{*}$ & $-17.471 *$ & $-41.924 *$ & $-58.434 *$ \\
\hline Toplam Harcama & $-0.0015^{*}$ & $-0.0051^{*}$ & $-0.0177 *$ & -0.0182 & -0.0182 \\
\hline
\end{tabular}

Medeni durum incelendiğinde tüm kantil değerlerinde $\% 1$ anlamlılık seviyesinde anlamlı ve negatiftir. Dolayısıyla medeni durumun sosyal yardım alma üzerinde etkisi bulunmaktadır. Bekâr bireylerden evli bireylere geçerken sosyal yardım miktarı azalmaktadır. Çalışma durumu değişkeni 0.10'uncu kantil değeri dışında $\% 1$ anlamlılık seviyesinde anlamlı ve negatiftir. Çalışan bireylerden çalışmayan bireylere geçerken sosyal yardım miktarı artmaktadır. Konut sahibi olma durumu incelendiğinde 0.50'inci kantil değeri dişında farklı anlamlılık seviyelerinde anlamlı ve pozitiftir. Konut sahibi olma ve sosyal yardım alma arasında doğru yönlü bir ilişki söz konusudur. Hanehalkı büyüklüğü istatistiksel olarak tüm kantil değerleri için \%1 anlamlılık düzeyinde anlamlı ve negatiftir. Dolayısıyla sosyal yardım alma üzerinde etkisi bulunmaktadır. Hanehalkındaki birey sayısı arttıkça daha az sosyal yardım alındığı sonucuna ulaşılmaktadır. Toplam harcama değişkeni 0.75 ve 0.90 kantil değerleri dişında istatistiksel olarak \%1 anlamlılık seviyesinde anlamlı ve negatiftir. Anlamlı sonuçlar; toplam harcama ile sosyal yardım ilişkisinin ters yönlü olduğunu göstermektedir.

2011 yılı için katsayı tahminlerinin test istatistikleri Tablo 5 incelendiğinde cinsiyet değişkeni tüm kantil değerleri için $\% 1$ anlamlılık düzeyinde anlamlı ve negatiftir. Kadınların erkeklerden daha fazla sosyal yardım aldığı sonucuna ulaşılmaktadır. Yaş değişkenin katsayı değişkeni test istatistiklerine bakıldığında diğer yılların aksine tüm kantil değerleri için anlamlı sonuç elde edilememiştir. 2011 yılı için yaş değişkeninin sosyal yardım alma üzerine etkisi 
bulunmamaktadır. Eğitim durumu incelediğinde tüm kantil değerleri için \%1 anlamlılık seviyesinde anlamlı ve pozitiftir. Bu doğrultuda eğitim ile sosyal yardım arasında doğru yönlü bir ilişki söz konusudur. Bir diğer gösterge olan medeni durum değişkeni, tüm kantil değerleri için \%1 anlamlılık düzeyinde anlamlı ve negatiftir. Evli bireyler, bekâr bireylerden daha az sosyal yardım almaktadir.

Çalışma durumuna bakıldığında tüm kantil değerleri için \%1 anlamlılık seviyesinde anlamlı ve negatiftir. Çalışan bireylerin çalışmayan bireylerden daha az sosyal yardım aldığı sonucuna ulaşılmıştır. Konutta mülkiyet durumu incelendiğinde 0.10 ve 0.90 'ıncı kantil değerleri dışında $\% 1$ anlamlılık seviyesinde anlamlı ve pozitiftir. Konut sahibi olmayan bireylerin, konut sahibi olan bireylerden daha az sosyal yardım aldığ sonucu ortaya çıkmıştır. Hanehalkı büyüklüğ̈ incelendiğinde tüm kantil değerleri için \%1 anlamlılık seviyesinde anlamlı ve negatiftir. Hanehalkındaki birey sayısı ile sosyal yardım alma arasında ters yönlü bir ilişki olduğu görülmektedir. Toplam harcama değişkeni 0.10 'uncu kantil değeri (\%10) hariç diğer kantil değerinde $\% 1$ anlamlılık seviyesinde anlamlı ve pozitiftir. Harcama değişkeni ile sosyal yardım arasında pozitif yönlü bir ilişki olduğu sonucuna ulaşılmaktadır.

Tablo 5: 2011 Yılı Model Tahmin Sonuçları

\begin{tabular}{|c|c|c|c|c|c|}
\hline Değişkenler & Q10 & Q25 & Q50 & Q75 & Q90 \\
\hline Cinsiyet & $-323.1 *$ & $-958.1^{*}$ & $-1705.5 *$ & $-2493.1 *$ & $-3516.5^{*}$ \\
\hline Yaş & -4.117 & 6.387 & 12.207 & 28.109 & -17.185 \\
\hline Eğitim Durumu & $21.233^{*}$ & $61.818^{*}$ & $254.8^{*}$ & $558.3^{*}$ & $848.9^{*}$ \\
\hline Medeni Durum & $-199.9 *$ & $-721.6^{*}$ & $-1654.1 *$ & $-1951.2 *$ & $-1615.2 *$ \\
\hline Çalışma Durumu & $-82.57 *$ & $-144.6^{*}$ & $-462.3^{*}$ & $-924.6^{*}$ & $-1259.8 *$ \\
\hline Konut Sahibi & 11.785 & $53.439 *$ & $133.4^{*}$ & $271.7^{*}$ & 229.9 \\
\hline HHB & $-22.031^{*}$ & $-46.170 *$ & $-109.2 *$ & $-228.1 *$ & $-350.3 *$ \\
\hline Toplam Harcama & $0.0075 * * *$ & $0.0417 *$ & $0.1528 *$ & $0.4565^{*}$ & $1.125^{*}$ \\
\hline
\end{tabular}

Tablo 6'daki 2015 yılı sonuçlarına göre cinsiyet değişkeni incelendiğinde tüm kantil değerleri için \%1 anlamlılık seviyesinde anlamlı ve negatiftir. Erkeklerin kadınlardan daha az sosyal yardım aldığı görülmektedir. Yaş değişkeni 0.10'uncu kantil değeri için \%10 anlamlılık düzeyinde pozitif ve anlamlıdır. Bu sonuca göre bireyin yaşı arttıkça daha fazla sosyal yardım almaktadır. Eğitim durumu 0.90'ınc1 kantil değeri dışında diğer kantil değerleri için anlamlı ve pozitiftir. Sosyal yardım ile eğitim durumu arasında doğru yönlü bir ilişki olduğu sonucuna ulaşılmaktadır. Medeni durum katsayı değişkeni test istatistiklerine bakıldığında tüm kantil değerleri için \%1 anlamlılık seviyesinde anlamlı ve negatiftir. Dolayısıyla bekâr bireylerin evli bireylerden daha fazla sosyal yardım aldığ görülmektedir. 
Çalışma durumu 0.10 ve 0.90 'ıncı kantil değerleri dışında anlamlı ve negatiftir. Anlamlı çıkan kantil değerleri doğrultusunda çalışmayan bireylerin, çalışan bireylerden daha fazla sosyal yardım aldığı sonucuna ulaşılmaktadır. Konut sahibi değişkeni incelendiğinde $\% 1$ ve $\% 10$ anlamlılık seviyesinde anlamlı ve pozitif çıkan 0.50 ve 0.75 'inci kantil değerleri için sosyal yardım alma arasında doğru yönlü bir ilişki söz konusudur. Hanehalkı büyüklüğü tüm kantil değerleri için \%1 anlamlılık seviyesinde anlamlı ve negatiftir. Hanehalkındaki birey sayısındaki artış sosyal yardım miktarını azaltmaktadır. Son olarak toplam harcama değişkeni incelendiğinde 0.10 'uncu kantil değeri (negatif) dişında pozitif ve $\% 1$ anlamlılık seviyesinde anlamlıdır. Toplam harcama değişkeni ile sosyal yardım arasında pozitif yönlü bir ilişki olduğu sonucuna ulaşılmaktadır.

Tablo 6: 2015 Yılı Model Tahmin Sonuçları

\begin{tabular}{|c|c|c|c|c|c|}
\hline Değişkenler & Q10 & Q25 & Q50 & Q75 & Q90 \\
\hline Cinsiyet & $-828.9 *$ & $-1762.3^{*}$ & $-2318.5^{*}$ & $-3372.3^{*}$ & $-3829.5^{*}$ \\
\hline Yaş & $13.841 * * *$ & 8.7014 & 71.061 & 50.827 & -50.139 \\
\hline Eğitim Durumu & $27.459 * *$ & $65.571 *$ & $108.7^{*}$ & $215.6^{*}$ & 359.5 \\
\hline Medeni Durum & $-682.7 *$ & $-1677.1 *$ & $-3348.3^{*}$ & $-25.507 *$ & $-5135.3^{*}$ \\
\hline Çalışma Durumu & 12.070 & $-92.296 *$ & $-175.7 * *$ & $4227.3 *$ & 527.1 \\
\hline Konut Sahibi & 16.112 & 44.475 & $208.9^{*}$ & $378.6 * * *$ & -78.216 \\
\hline HHB & $-57.264 *$ & $-102.1 *$ & $-206.1^{*}$ & $-357.2 *$ & $-483.8^{*}$ \\
\hline Toplam Harcama & $-0.0296^{*}$ & $0.0880 *$ & $0.1850 *$ & $0.5452 *$ & $1.3634 *$ \\
\hline
\end{tabular}

\section{Tartışma ve Sonuç}

Bu çalışmada, Türkiye'de 2003-2015 yıllarında ayni ve nakdi sosyal yardımların alınmasında etkili olan sosyoekonomik ve demografik belirleyicileri ilgili yıllar için Hanehalkı Bütçe Anketi mikro veri seti üzerinden kantil regresyon yöntemi yardımıyla analiz edilmiştir. Çalışmada, bağımlı değişkeni oluşturan toplam yardımlar değişkeni, yıllık olarak bireylere yapılan on bir farklı nakdi ve ayni yardım kaleminin toplamı olarak oluşturulmuştur. Sosyal yardımların alınmasında belirleyici faktörleri tespit etmek amacıyla uygulanan kantil regresyon yönteminden elde edilen en önemli bulgu; bireylerin yaşı arttıkça daha fazla sosyal yardım aldığıdır. Bireylerin yaşı arttıkça daha fazla sosyal yardım alması, yaşla birlikte ihtiyaçların artması ve bu ihtiyaçları karşılama gücü azalacağı düşünüldüğünde sonucun beklentiler doğrultusunda olduğu söylenebilir. Analizden elde edilen bir diğer bulgu, cinsiyetin sosyal yardım alma üzerine önemli bir değişken olduğu ve incelenen bütün yıllar için kadınların erkeklerden daha fazla sosyal yardım aldığı sonucudur. Kadınların işgücüne katılım oranı, yapılan sosyal yardımlardan faydalanma durumu gibi kriterler göz önüne alındığında sonuç beklentiler doğrultusundadır. 
Bireyin eğitim seviyesindeki artışın sosyal yardımlara olan ihtiyacı azaltıcı yönde bir etki göstermesi genel kabul görülmektedir. 2007 yılında bu doğrultuda doğrultusunda sonuç elde edilmiştir. Ancak çalışmada sosyal yardım değişkeni, yıllık öğrenci burs geliri gibi nakdi ve ayni yardımları da kapsamaktadır. Eğitim seviyesi arttıkça söz konusu yardımların da nominal olarak artması beklenmektedir. Bir diğer değişken çalışma durumu incelendiğinde; sosyal yardım alıcılarının hedef kitlesi sosyal güvencesi olmayan kişilerdir ve herhangi bir işte çalışmayan bireylerin sosyal yardımlara olan ihtiyacının bütün yıllar için arttığı görülmektedir. Medeni durumun sosyal yardım alma üzerine etkisi incelenen bütün yıllar için; bekâr (hiç evlenmedi, dul, boşanmış) bireylerin evli bireylerden daha fazla sosyal yardım aldığı görülmektedir. Bekârların hiç evlenmeyen, dul ve boşanmış bireyleri kapsaması ayrıca bu kişilere yapılan yıllık dul maaşı, nafaka gibi nakdi yardımların bağımlı değişken içerisinde yer alması nedeniyle evlilerden daha fazla yardım alması öngörüler doğrultusundadır.

Bütün yıllar için hanehalk1 büyüklüğü artıkça sosyal yardımların azaldığı görülmektedir. Hanedeki birey sayısı arttıkça haneye gelir getiren birey sayısında da artış yaşanması nedeniyle hanehalkı fazla olan hanelerin aldıkları sosyal yardım miktarının azaldığı söylenebilir. Çalışmada elde edilen bir diğer sonuç mülkiyet sahibi olan bireylerin daha fazla sosyal yardım alması, Öğülmüş (2011), Karagöl vd. (2013) ve Kırlıŏglu (2015)'nun çalışmalarında da gözlemlenen kırsal kesimin daha yoksul olduğu, gecekondu, müstakil evlerde ikamet edip alıcıların yakacak yardımından da yararlanabildiği göz önüne alındığında çalışmadan elde edilen sonuç literatür ile uyumludur.

Sosyal yardımların karşılıksız olarak yoksul kesime sunulmasının bütçeye yük olduğu yönünde görüşler yer almaktadır. Herhangi bir hedefleme mekanizması kullanılmadığı durumda sosyal yardımlara ihtiyacı olmayan kişilerin de sosyal yardım alması maliyeti artırmaktadır. Bu yüzden doğru hedef kitlenin belirlenmesi, sosyal yardım alıcılarının genel bir profilinin çizilmesi önem arz etmektedir. Sosyal yardımlara ayrılan kaynakların etkin şekilde kullanılması, siyasi bir araç olarak ve yetkililerin inisiyatifi söz konusu olmaksızın rasyonel seçimle belirlenen, doğru hedef kitleye, ihtiyaçları doğrultusunda sağlanması durumda maliyeti azalacaktır. Çıkarılan bu görüş literatürde Ahmed ve Bois (2002), Schady (2002), Bibi ve Muller (2008), Daşlı (2015) ile paralellik göstermektedir.

Elde edilen sonuçlar doğrultusunda sosyal yardımların program ve miktar açısından yıllar itibariyle artış gösterdiği ancak temeldeki problemlerin süregeldiği görülmektedir. Geleneksel aile yapısına dayalı bir sosyal yardım anlayışının ortaya çıkardığı problem olarak; kadınların daha fazla sosyal yardıma muhtaç olması gösterilebilir. Bu doğrultuda kadın istihdamının önündeki; bakım sorumluluğu, düşük eğitim seviyesi, beşerî sermaye yetersizliği gibi engellerin önüne geçilebilmesi ve nitelikli işgücü kalitesine sahip bireyler olarak üretime 
katılmaları sağlanabilir. Sosyal yardım programlarının sayısını artırmaktan ziyade alıcıların istek ve ihtiyaçları doğrultusunda etkinliğini ve verimliliğini artırmak, sosyal yardımlara olan bağımlılığın önüne geçebilmek ve sosyal yardım ihtiyacının kuşaklar arası miras aktarımının önüne geçebilecek politikalara öncelik verilmesi gerekmektedir.

Tüm dünyayı etkisi altına alan Covid-19 salgınıyla birlikte işten çıkarılmaların artması sosyal yardımlara olan talebin artmasına sebep olmuştur. Bu noktada doğru hedef kitleye yardımların ulaşması mevcut dönemde daha da önemli hale gelmiştir. Bu bağlamda gelecekte yapılacak araştırmalar bireysel bazda verileri kullanarak çalışmanın kapsadığı yılları ve değişkenleri genişletilebilir. Hane bazında verilere erişilmesi bu çalışmanın kısıtını oluşturmaktadır. Ayrıca salgın döneminde yapılan sosyal yardım alıcılarının profili çizilebilir ve sosyal yardımların etkinliği analiz edilebilir.

\section{Kaynakça}

Ahmed, A. U. ve Bouis, H. E. (2002). Weighing what's practical: proxy means tests for targeting food subsidies in Egypt. Food Policy, 27(5-6), 519-540.

Altındağ, Ö. (2019). Yoksulluk üzerine bir değerlendirme. Ufkun Ötesi Bilim Dergisi, 19(1), 81-114.

Aydın, K. ve Güloğlu, T. (2012). Türkiye'de nispi yoksulluğun sosyoekonomik analizi. Sosyal Siyaset Konferanslart Dergisi, 60, 89-118.

Bakan, S. ve Özdemir, H. (2012). Sosyal politika açısından CHP ile AKP'nin karşılaştırılması. Akademik Yaklaşımlar Dergisi.

Bibi, S. ve Muller, C. (2008). Focused transfer targeting against poverty evidence from Tunisia. Thema Working Paper, 90, 67-76.

Buchinsky, M. (1994). Changes in the US wage structure 1963-1987: Application of quantile regression. Econometrica, 62(2).

Buğra, A. ve Keyder, Ç. (2005). Poverty and social policy in contemporary Turkey. In Boğaziçi University Social Policy Forum.

Cafrı, R. (2009). Adana ilinde yoksulluğun analizi: Sinırlı bă̆ımlı değişkenli modellerle bir inceleme. Yayınlanmamış Yüksek Lisans Tezi, Çukurova Üniversitesi Sosyal Bilimler Enstitüsü Ekonometri Ana Bilim Dalı, Adana.

Çağlayan, E. ve Astar, M. (2012). A microeconometric analysis of household consumption expenditure determinants for both rural and urban areas in Turkey. American International Journal of Contemporary Research, 2(2), $27-34$ 
Canbay, T. ve Selim, S. (2010). Türkiye'de hanehalkı yoksulluğu. Ege Akademik Bakış, 10(2), 627.

Daşl1, Y. (2015). Sosyal yardımların sorunlu alanı: Muhtaçlık Tespiti. Cumhuriyet Üniversitesi Sosyal Bilimler Dergisi, 39(2), 136-151.

Datt, G., Simler, K. R., Mukherjee, S., ve Dava, G. (2000). Determinants of poverty in Mozambique: 1996-97. FCND Discussion Paper, 78.

Davino, C., Furno, M. ve Vistocco, D. (2013). Quantile regression: Theory and applications. United States of America: John Wiley \& Sons.

Esenyel, C. (2009). Türkiye'de ve Dünya'da şartlı nakit transferi uygulamalart. Sosyal Yardım Uzmanlık Tezi. Ankara: TC Başbakanlık Sosyal Yardımlaşma ve Dayanışma Genel Müdürlüğü.

Esping-Andersen, G. (1990). The three worlds of welfare capitalism. Great Britain: Princeton University Press.

Furno, M. ve Vistocco, D. (2018). Quantile regression: Estimation and simulation. United States of America: John Wiley \& Sons.

Geda, A., de Jong, N., Mwangi, S. K. ve Mwabu, G. (2005). Determinants of poverty in Kenya: A household level analysis. Economics Working Papers, 200544.

Gezer, E. ve Birecikli, Ş. Ü. (2016). Türkiye'de kamu kaynaklı sosyal yardımlar: Sansürlü regresyon analizi. Türk İdare Dergisi, 482.

Gürler, Ö. K., Emeç, H. ve Birecikli, Ş. Ü. (2017). Kamu destekli sosyal yardımlar üzerine ampirik bir çalışma: Türkiye örneği. Insan Hakları Ylllı̆̆ , Cilt 35, s. 97-114.

Hacımahmutoğlu, H. (2009). Türkiye'deki sosyal yardım sisteminin değerlendirilmesi. Devlet Planlama Teşkilatı Uzmanlık Tezi, Ankara.

Hao, L. ve Naiman, D. Q. (2007). Quantile regression. United States of America: Sage.

İpek, E.ve Sekmen, Ö. (2017). Effect of household heterogeneity on consumption expenditure: A simultaneous quantile regression analysis. The Empirical Economics Letters, 16(12).

Karagöl, E. T., Yıldırım, J., Atan, M., Eralp, A., Güneş, F. ve Sungur, M. (2013). Türkiye'de sosyal yardım yararlanıcılarını belirleyen faktörler. Gazi Üniversitesi İktisadi ve İdari Bilimler Fakültesi Dergisi, 15(1), 1-22. 
Karagöl, E. T. ve Dama, N. (2015). Geçmişten günümüze sosyal yardımlar. Siyaset, Ekonomi ve Toplum Araştırmaları Vakfi, 139.

Kırlığlu, M. (2015). Sosyal ve ekonomik destek alan ailelerde yoksulluk, sağllk ve yaşam kalitesinin değerlendirilmesi: Konya örneği. Yüksek Lisans Tezi. Selçuk Üniversitesi Sağlık Bilimleri Enstitüsü.

Koenker, R. ve Bassett Jr, G. (1978). Regression quantiles. Econometrica, 46(1), 33-50.

Koenker, R. ve Hallock, K. F. (2001). Quantile regression. Journal of Economic Perspectives, 15(4), 143-156.

Koenker, R. ve Xiao, Z. (2002). Inference on the quantile regression process. Econometrica, 70(4), 1583-1612.

Koenker, R. (2017). Quantile regression: 40 years on. Annual Review of Economics, 9, 155-176.

Mukherjee, S. ve Benson, T. (2003). The determinants of poverty in Malawi, 1998. World Development, 31(2), 339-358.

Öğülmüş, S. (2011). Sosyal yardım algısı ve yoksulluk kültürü. Sosyal Politika Çalışmaları Dergisi, 26(26), 83-96.

Özdemir, A, Ö. (2019). Bir sosyal koruma bileşeni olan sosyal yardımların yoksulluk üzerine etkisi: Ampirik bir uygulama. Journal of International Social Research, 12(63).

Pacek, A. ve Freeman, B. (2017). The welfare state and quality of life: A crossnational analysis.

Pashardes, P. ve Polycarpou, A. (2011). Poverty and labour market participation of public assistance recipients in Cyprus. Cyprus Economic Policy Review, 5(1), 23-42.

Salduz, Ç. ve Arslankoç, S. (2021). Yoksullukla mücadele politikalarında bir çözüm olarak sosyal yardımlar: sosyal hizmet odaklı bir değerlendirme. Oltu Beşeri ve Sosyal Bilimler Fakültesi Dergisi.

Schady, N. R. (2002). Picking the poor: indicators for geographic targeting in Peru. Review of Income and Wealth, 48(3), 417-433.

Sigeze, Ç. ve Şengül, S. (2018). Türkiye'de yoksulluğun rassal etkiler multinomial logit model ile incelenmesi. Dokuz Eylül Üniversitesi Sosyal Bilimler Enstitüsü Dergisi, 20(4), 503-521. 
Sosyal Yardımlar Genel Müdürlüğü, https://www.ailevecalisma.gov.tr/sygm/programlarimiz/sosyal-yardimprogramlarimiz/ (Erişim Tarihi: 01 Mart 2020)

Şirin, M. (2021). Sosyal ve ekonomik destek hizmetlerinden yararlanan bireylerin aile işlevleri üzerine bir inceleme: Karadeniz Ereğli örneği, Yüksek Lisans Tezi.

Şişman, Y. (2017). Türkiye'de sosyal politikanın dünü, bugünü: hayırseverliğin kurumsallaşması mı? Gelişim mi?. Optimum Ekonomi ve Yönetim Bilimleri Dergisi, 4(2), 1-22.

Taşç1, F. (2007). 1980 sonrası Türkiye'de sosyal yardımların analizi. Yayımlanmamış Yüksek Lisans Tezi, İstanbul Üniversitesi, İstanbul.

Taşçı, F. (2017). Türkiye'de sosyal politika ve dönüşüm: Zihniyet, aktörler, uygulamalar. Siyaset, Ekonomi ve Toplum Araştırmaları Vakfi, 28-38.

Tatlıdil, H. ve Demirağ, İ. (2014). Türkiye'de yoksulluğun sosyoekonomik ve demografik değişkenlerle ilişkilerinin lojistik regresyon ve mars yöntemleri kullanılarak incelenmesi. Tisk Akademi, 9(17).

TÜİK. Hanehalkı Bütçe Anketi Verileri (2003-2015), Ankara.

TÜİK (2008). Tüketim harcamaları, yoksulluk ve gelir dağılımı, Ankara.

Türkoğlu, İ. (2013). Sosyal devlet bağlamında Türkiye'de sosyal yardım ve sosyal güvenlik. Akademik Incelemeler Dergisi, 8(3), 275-305.

Türkiye Cumhuriyeti Aile ve Sosyal Hizmetler Bakanlığı, (2021).https://www.aile.gov.tr/bakanlik/hakkinda/tarihce/, (Erişim Tarihi: 09.05.2021)

Ulutaş, Ç. Ü. (2017). Türkiye refah rejiminin dönüşüm sürecinde sosyal yardım sistemi. Emek Araştırma Dergisi (GEAD), 8(12), 27-48. 


\section{Determinants of Social Benefit to Households in Turkey}

\section{Extended Abstract}

\section{Introduction}

Social policy is the set of tools that the governments use to increase the welfare of the society and reach the targets in social protection policies. Among these tools, social benefit policies are considered an important public instrument, especially in combating poverty. Studies on social benefit in the academic literature are generally on the relationship between social benefit and poverty. Besides being important to investigate the relationship between social benefit and poverty, it is also important to determine the socio-economic profile of social assistance recipients and provide social benefits in line with the needs of the target audience. In this regard, this study aims to analyze the socioeconomic determinants of the social benefit provided to households. We used the Household Budget Survey micro data set, which has been regularly conducted by the Turkish Statistical Institute (TurkStat) every year since 2002. The socioeconomic determinants of social benefits, which consist of the sum of in-kind and cash aids to households provided to households between the years 2003 and 2015, were analyzed using the quantile regression method to examine them comparatively four years apart.

\section{Method}

In the study, the social benefit dependent variable was determined as the sum of annual in-cash and in-kind aids provided to all individuals in the household. Ten variables in household budget survey individual data set constitute the dependent variable of in-kind and in-cash social benefits. The variables of the gender, age, education status, marital status, and employment status of the household head, and the owners were taken as independent variables. In the study, the effects of independent variables such as age, gender, marital status, and educational status on receiving social benefits were investigated using the quantile regression model. The quantile regression method proposed by Koenker and Bassett (1978) allows for analysis of the fully conditional distribution properties of the dependent variable. Statistical analysis of linear and nonlinear response models for the conditional quantile function is a comprehensive approach. The quantile regression method has become more important as data sources and awareness of the importance of heterogeneity increased. Moreover, the quantile regression model provides an opportunity to estimate the entire conditional distribution of $y$ for a given $\mathrm{x}$. More quantile regression values have the potential to provide more information. Furthermore, the quantile regression enables the estimation of different results depending on the various quantities of the social benefit amount, which is the dependent variable. The estimation values can be obtained for each desired quantile level. In the study, estimation results were obtained for the 10th, 25th, 50th, 75th, and 90th quantiles, which are frequently preferred in the literature. The quantile regression provides information on the conditional distribution of social benefits, which is the dependent variable.

\section{Results and Discussion}

The most important finding obtained from the analyses is that individuals receive more social benefits as their age increases. Considering that individuals receive the more social benefit as their age increases, needs increase with age, and their ability to meet these needs decreases, the result is as expected. Moreover, gender is an important variable in receiving the social benefit, and women receive more benefits than men for all analysis periods. It is generally accepted that if the education level of the individual increases the need for social benefit decreases. In the study, the social benefit variable includes in-kind and cash aids such as annual student scholarships. As the level of education increase In this study, the socioeconomic and demographic determinants of in-kind and cash social benefit in Turkey between 2003 and 2015 were analyzed with the help of the quantile regression method over the Household Budget Survey micro data set. The most important finding obtained from the analyses is that individuals receive more social benefits as their age increases. Considering that individuals receive the more social benefit as their age increases, needs 
increase with age, and their ability to meet these needs decreases, the result is as expected. Moreover, gender is an important variable in receiving the social benefit, and women receive more benefits than men for all analysis periods. It is generally accepted that if the education level of the individual increases the need for social benefit decreases. In the study, the social benefit variable includes in-kind and cash aids such as annual student scholarships. As the level of education increases, these aids are expected to increase nominally. When the working status is examined, it is observed that the target audience of social benefit recipients is people without social security. The need for the social benefit for unemployed individuals has been increasing for all years. On the other hand, single (never married, widowed, divorced) individuals receive more social benefits than married individuals. It is thought that single people receive more benefits than married people since they include individuals who have never married, widowed, and divorced, and cash benefits such as annual widow's salary and alimony are included in the dependent variable. In addition, the social benefit decreases as the household size increases. It can be said that as the number of individuals in the household increases, the amount of social benefit decreases in these households due to the increase in the number of individuals who earn income. Finally, individuals who own property receive the more social benefit. The result obtained from the study is consistent with the literature considering that households living in rural areas are poorer, and households living in slums and detached houses can also benefit from fuel benefit.

\section{Conclusion}

In line with the results obtained, it is seen that social benefit has increased over the years in terms of program and amount, but the underlying problems continue. Rather than increasing the number of social benefit programs, it is necessary to increase their effectiveness and efficiency in line with the wishes and needs of the recipients. In addition, the increase in layoffs with the Covid-19 epidemic, which affected the whole world, caused an increase in the demand for social benefits. In future studies, the profile of social benefit recipients during the epidemic can be drawn and the effectiveness of social benefit can be analyzed. 